\title{
A novel simple method for quantifying bacteria from endotracheal aspirates
}

\author{
P. G. FLANAGAN, A. PAULL and R. A. BARNES \\ Department of Medical Microbiology and Public Health Laboratory, University Hospital of Wales, Cardiff CF4 \\ $4 X W$
}

\begin{abstract}
A convenient dipstrip method (Bacteruritest ${ }^{T M}$; Mast Diagnostics) for bacterial quantification was evaluated with 42 endotracheal aspirates. For 31 specimens, the dipstrip method yielded counts within a 10-fold range of surface plate counts. Two specimens yielded counts by the dipstrip within a 100 -fold range of plate counts. Six specimens yielded confluent growth at the greatest dilution tested by the dipstrip method, and counts $>10^{10} \mathrm{cfu} / \mathrm{ml}$ in the surface plate method. Three specimens yielded no detectable growth by the dipstrip and surface plate counts $<10^{2} \mathrm{cfu} / \mathrm{ml}$. Dipstrips provide a cheap, convenient method for the routine quantification of the bacterial load in endotracheal aspirates.
\end{abstract}

\section{Introduction}

Quantitative cultures are a valuable aid in the diagnosis of nosocomial pneumonias in ventilated patients [1]. Serial dilution methods have been used to distinguish tracheobronchial colonisation from significant lower respiratory tract infection [2]. However, these methods are laborious and time consuming [3, 4]. Filter paper strips ('dipstrips') of a standard porosity, which absorb a known volume of fluid which is then delivered to the surface of an agar plate, are used widely to measure bacterial loads in urine specimens [5]. The use of dipstrips as a convenient method of quantifying bacterial loads in endotracheal aspirate specimens was evaluated by comparison with a conventional surface agar plate (viable count) method.

\section{Materials and methods}

The number of viable bacteria was quantified in 42 endotracheal aspirates obtained over a 2-month period from 39 ventilated adult patients with or without clinical signs of pneumonia. After liquefaction and homogenisation of the specimen in an equal volume of Sputasol (Oxoid-Unipath Ltd), 10-fold dilutions to $10^{10}$ in sterile distilled water were prepared. Each dilution was sampled once with a dipstrip (Bacteruritest strips, Mast Diagnostics) which was then placed briefly on the surface of a blood agar plate (horse blood $5 \%$, Oxoid-

Received 20 Nov. 1995; accepted 29 Dec. 1995.

Corresponding author: Dr P. G. Flanagan.
Unipath Ltd) as recommended by the manufacturer. The dipstrip produced a $12 \times 6 \mathrm{~mm}$ imprint on the agar, from which the number of colonies could subsequently be counted. In parallel, with the same dilution series, five $10-\mu 1$ drops of each dilution were placed on the surface of a blood agar plate [4]. All plates were incubated aerobically for $18 \mathrm{~h}$ at $37^{\circ} \mathrm{C}$. Colony counts from the dipstrip imprints were interpreted as recommended for urine samples, taking each colony as representing $c .5000 \mathrm{cfu} / \mathrm{ml}$ of the diluted material [6]. The total number of colonies obtained with the surface plate method was used to calculate the viable bacterial count in the specimen (modified Miles and Misra method) [4].

\section{Results and discussion}

The number of viable bacteria was quantifiable by both methods for 33 specimens from 32 patients and estimates of the bacterial load concurred within a 10fold range for 31 of these (Fig. 1a). Six specimens produced confluent growth at the highest dilution in both methods. Three specimens produced no growth by the dipstrip method and low surface plate counts in the range $10-10^{2} \mathrm{cfu} / \mathrm{ml}$. Two specimens produced results which differed by two 10-fold dilutions; one specimen yielded counts of $10^{3} \mathrm{cfu} / \mathrm{ml}$ (surface count) and $10^{5} \mathrm{cfu} / \mathrm{ml}$ (dipstrip) and the other gave $10^{2} \mathrm{cfu} / \mathrm{ml}$ (surface count) and $10^{4} \mathrm{cfu} / \mathrm{ml}$ (dipstrip). These discrepancies may have been due to the nature of the organisms involved, for example, viable counts of gram-positive cocci are often unreliable. However, this 

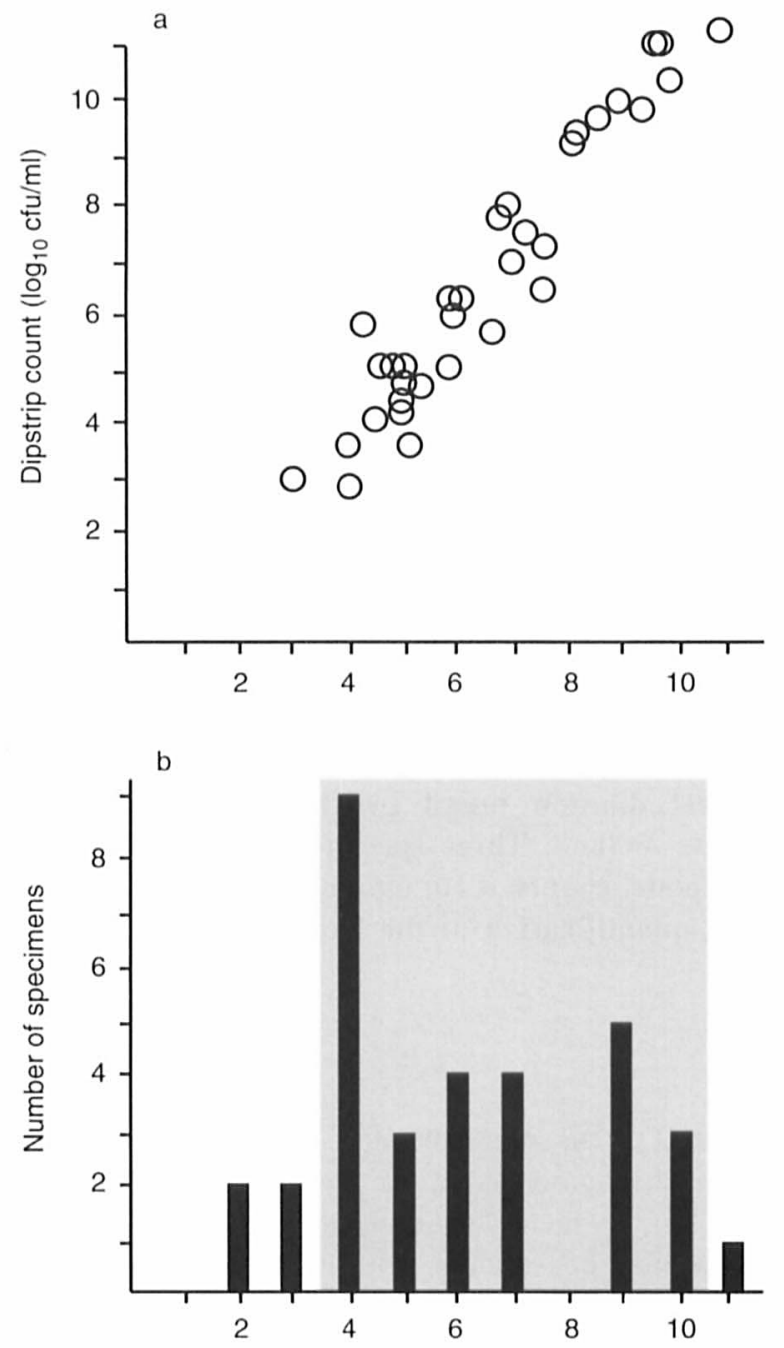

Surface plate count $\left(\log _{10} \mathrm{cfu} / \mathrm{ml}\right)$

Fig. 1. (a) Correlation between dipstrip count and surface plate count. (b) Distribution of bacterial loads as determined by surface plate count. Shaded area represents the range of values which could be determined with the dipstrip method with the three proposed dilutions (see text).

possibility remains uncertain as organisms were not identified in the present study. Dipstrips, therefore, produced an acceptably accurate quantitative estimate of bacterial load (i.e., within a ten-fold range of surface counts) in the range $10^{3} \mathrm{cfu} / \mathrm{ml}$ to $>10^{10} \mathrm{cfu} / \mathrm{ml}$.

The results of this study show that dipstrips facilitate bacterial quantification in endotracheal aspirates without compromising accuracy. It was possible to count up to c. 80-100 colonies on a dipstrip imprint. Thus the range of accurate load determination by dipstrips would be $\left(5 \times 10^{3}\right)-\left(5 \times 10^{5}\right) \mathrm{cfu} / \mathrm{ml}$ for a two-fold dilution, $\left(5 \times 10^{5}\right)-\left(5 \times 10^{7}\right) \mathrm{cfu} / \mathrm{ml}$ for a dilution of $10^{2}$, etc. (Fig. 1b). If anaerobic infection was suspected, dipstrip counts could be performed aerobically and anaerobically. Our specimens were routine clinical samples chosen at random and it seems reasonable to assume that the range of bacterial loads found is representative of those in ventilated patients.
Various quantitative thresholds have been proposed to distinguish respiratory tract colonisation from true infection and aid diagnosis of ventilator-associated pneumonia (e.g., $10^{5} \mathrm{cfu} / \mathrm{ml}$ for endotracheal aspirates) [7]. These diagnostic thresholds could distinguish those specimens requiring further work - isolate identification and antimicrobial susceptibility testing - from those of little clinical significance. Dipstrip plating of three dilutions (two-fold, $10^{2}$ and $10^{4}$ ) would allow quantitative estimation of endotracheal aspirate loads in the range $10^{4}-10^{10} \mathrm{cfu} / \mathrm{ml}$, within which most of the proposed diagnostic thresholds lie. Beneficial effects for the laboratory would be savings, in time and expense, and concentration of effort on clinically important specimens. Each dipstrip costs 0.5 pence and c. 10 imprints could be applied from different dilutions to a single blood agar plate or five imprints if each specimen was sampled in duplicate. The surface plate count method as used above requires a blood agar plate (price $=c$. 30 pence) for each dilution used in addition to the cost of diluent and disposable pipettes. The number of bacteria in endotracheal aspirates is not routinely determined in this laboratory but bronchial brush specimens, although received rarely, are investigated by a surface plate count method. The low media cost associated with the dipstrip method may enable the quantification of bacterial loads in endotracheal aspirates on a routine basis in the future. Dipstrips may be suitable for the quantification of bacterial loads in other specimens, e.g. bronchoalveolar lavages, if samples were homogenised appropriately.

We are grateful to Dr J. T. Magee for his helpful advice and constructive criticism of the manuscript.

\section{References}

1. El-Ebiary M, Torres A, Gonzàlez $\mathrm{J}$ et al. Quantitative cultures of endotracheal aspirates for the diagnosis of ventilatorassociated pneumonia. Am Rev Respir Dis 1993; 148: 15521557.

2. Marquette $\mathrm{CH}$, Georges $\mathrm{H}$, Wallet $\mathrm{F}$ et al. Diagnostic efficiency of endotracheal aspirates with quantitative bacterial cultures in intubated patients with suspected pneumonia. Comparison with the protected specimen brush. Am Rev Respir Dis 1993; 148: $138-144$.

3. Duguid JP, Collee JG, Fraser AG. Laboratory strategy in the diagnosis of infective syndromes. In: Collee JG, Duguid JP, Fraser AG, Marmion BP (eds) Mackie and McCartney Practical medical microbiology, 13th edn. Edinburgh, Churchill Livingstone. 1989: 600-649.

4. Brown R, Poxton IR, Wilkinson JF. Centrifuges, colorimeters and bacterial counts. In: Collee JG, Duguid JP, Fraser AG, Marmion BP (eds) Mackie and McCartney Practical medical microbiology, 13th edn. Edinburgh, Churchill Livingstone. 1989: 200-247.

5. Leigh DA, Williams JD. Method for the detection of significant bacteriuria in large groups of patients. J Clin Pathol 1964; 17: 498-503.

6. Lewis DA. Bacteriology of urine. In: Hawkey PM, Lewis DA (eds) Medical bacteriology: a practical approach. Oxford, IRL Press. 1989: 1-19.

7. Torres A, Martos A, Puig de la Bellacasa $\mathrm{J}$ et al. Specificity of endotracheal aspiration, protected specimen brush, and bronchoalveolar lavage in mechanically ventilated patients. Am Rev Respir Dis 1993; 147: 952-957. 